\title{
ЮРИСПРУДЕНЦИЯ
}

DOI: $\underline{10.17805 / g g z .2018 .3 .8}$

\section{Закон Великобритании об уголовных финансах 2017 года для организаций}

Б. А. Асриян

Московский гуманитарный университет

Уклонение от уплаты налогов давно считается преступлением в разных государствах. Однако до сих пор трудно было возложить ответственность на лии и предприятия, способствующие уклонению от уплаты налогов, а также на тех, кто знает об этом, но не может предотвратить его. Закон Великобритании об уголовных финансах 2017 2. направлен на преодоление этой трудности путем создания преступлений строгой ответственности, которые не требуют доказательств знания, намерения, безрассудства или «направленности умысла». Таким образом, даже непреднамеренные действия сотрудников могут привести к уголовной ответственности организации.

Статья подготовлена на основе доклада, представленного на Всероссийской научной конференции «Моисеевские чтения» (Москва, 26 мая 2018 г.).

Ключевые слова: преступление; налоги; Великобритания; закон; уклонение от уплаты налогов; риски

\section{UK Criminal Finances Act 2017 for Organizations}

B. A. Asriyan

Moscow University for the Humanities

Tax evasion has been considered an infringement in different states for a long time. Nevertheless, it is still difficult to impose responsibility on persons and corporate entities or partnerships that aid tax evasion as well as on those who know about it, but cannot prevent it. The UK Criminal Finances Act 2017 seeks to overcome this difficulty by creating crimes of strict liability that do not demand evidences of awareness, intention, recklessness or "direction of criminal intent". Thus, even unintentional actions of employees may lead to criminal liabilities of their organizations.

The article is based on the report presented at the All-Russian conference "Moiseev Readings" (Moscow, May 26, 2018).

Keywords: crime; taxes; Great Britain; law; tax evasion; risks 
Уклонение от уплаты налогов давно считается преступлением в разных государствах (Ларичев, Трунцевский, Баграев, 2007). 30 сентября 2017 г. в Великобритании вступил в силу Закон об уголовных финансах (Criminal Finances Act 2017) (Трунцевский, Марьин, 2017). В качестве уголовного преступления для компаний, других корпоративных органов и партнерств - независимо от того, созданы ли они в соответствии с законодательством Великобритании или иностранным правом («соответствующие органы»), которые не препятствуют лицу, связанному с ними (например, работнику, агенту, советнику, посреднику, подрядчику или поставщику услуг) («связанное лицо»), преступно способствуя уклонению от уплаты налогов в Великобритании или за рубежом (до тех пор, пока существует связь с Великобританией в отношении любого уклонения от уплаты иностранных налогов).

Речь идет о преступлении строгой ответственности - это означает, что если связанное с организацией лицо преступно уклоняется от уплаты налогов, действуя от имени соответствующего органа, то соответствующая организация будет нести ответственность, если только она не сможет доказать наличие у нее разумных профилактических процедур. Это новое преступление аналогично преступлению подкупа (The UK Bribery Act — UKBA) 2010 г., состоящему в неспособности организации предотвратить взяточничество (Ищук, 2018: 45). Таким образом, чтобы избежать привлечения к уголовной ответственности за преступные деяния связанных с организацией лиц и не подвергнуться неограниченным штрафам, организации должны ввести в действие разумные профилактические процедуры.

В то время как на первый взгляд закон может казаться актуальным только для бухгалтеров, юристов, банков / компаний финансовых услуг и налоговых консультантов, которые явно подвергаются высокому риску связанных с ними лиц, имеющих возможность преступно совершить уклонение от уплаты налогов, все организации даже за пределами сектора финансовых услуг должны провести, по крайней мере, оценку риска.

Любой сектор хозяйственной деятельности потенциально подпадает под действие Закона, включая благотворительные организации, а также коммерческие корпорации и партнерства.

Следует подчеркнуть, что законодательство направлено только на борьбу с преступлениями, совершенными теми, кто действует от имени соответствующего органа, такого как компания или партнерство. Законодательство направлено на пресечение неправомерного использования законных продуктов и услуг, которые предоставляются клиентам добросовестно, не содержит сведений о том, что отдельные консультанты и соответствующие органы не знали о том, что их продукты предназначены в целях уклонения от уплаты налогов. 
Кроме того, новый закон нацелен на преднамеренное и нечестное поведение на уровне налогоплательщиков. Они не создают каких-либо новых правонарушений на индивидуальном уровне - если деятельность будет считаться уклонением от уплаты налогов в соответствии с действующим законодательством, то это будет правонарушением. Аналогично, если деятельность в настоящее время не будет рассматриваться как уклонение от уплаты налогов (т. е. является «законным» уклонением от уплаты налогов), то новый закон не делает ее уклонением от уплаты налогов.

Если до последнего времени отдельные работники могли быть привлечены к уголовной ответственности за содействие уклонению от уплаты налогов, то их работодатель часто находится вне досягаемости уголовного законодательства. Эти новые правонарушения, связанные с непринятием корпоративных мер по предотвращению уклонения от уплаты налогов, устраняют эту трудность.

Если организация сможет продемонстрировать, что она ввела в действие систему разумных превентивных процедур, которая выявляет и смягчает риски, связанные с уклонением от уплаты налогов, то судебное преследование вряд ли будет проводиться.

Процедуры предотвращения, установленные соответствующими органами для предотвращения уклонения от уплаты налогов (Трунцевский, 2010: 166), должны основываться на принципах, которые не являются предписывающими и должны быть гибкими и ориентированными на результат. Что является ключевым, так это то, что любые процедуры пропорциональны риску. Эти принципы отражают указания UKBA, поэтому многие организации должны быть знакомы с ними:

1. Оценка риска. Соответствующий орган должен оценить характер и степень своей подверженности риску тех, кто действует от его имени, принимая участие в преступной деятельности, способствующей уклонению от уплаты налогов.

2. Соразмерность процедур профилактики, основанных на рисках. Разумные процедуры соответствующей организации будут соразмерны риску лиц, связанных с совершением уклонения от уплаты налогов. Это будет зависеть от характера, масштабов и сложности деятельности соответствующего органа.

3. Обязательства высшего уровня. Руководство на высшем уровне должно быть привержено предотвращению участия связанных с организацией лиц в преступной деятельности по уклонению от уплаты налогов. Они должны способствовать формированию культуры в рамках соответствующей организации, в которой деятельность, направленная на содействие уклонению от уплаты налогов, никогда не будет приемлемой. 
4. Должная осмотрительность. Организация применяет процедуры due diligence (Трунцевский, Карпович, 2013), используя основанный на рисках подход в отношении лиц, которые выполняют или будут выполнять услуги от имени организации, чтобы смягчить выявленные риски.

5. Коммуникация (включая обучение). Организация стремится обеспечить, чтобы ее превентивные стратегии и процедуры были доведены до сведения, внедрены и были понятны в рамках всей организации, посредством внутренней и внешней связи, включая обучение.

6. Мониторинг и обзор. Организация контролирует и пересматривает свои профилактические процедуры и при необходимости вносит улучшения.

Возможные штрафы в соответствии с этим законом являются неограниченными, и осуждение может также повлечь за собой такие наказания, как утрата права участвовать в торгах по публичным контрактам, не говоря уже о значительном вреде для репутации.

Внутренние преступления Великобритании по данному закону разделены на три «вида»:

1. Преступное уклонение налогоплательщика от уплаты налогов: на данном этапе требуется уклонение налогоплательщика от уплаты налогов в Великобритании или поведение, приравниваемое к недобросовестному или сознательному уклонению от уплаты налогов.

2. Преступное облегчение уклонения от уплаты налогов «ассоциированным лицом» соответствующего органа: этот этап требует преднамеренного или небрежного действия по облегчению уклонения от уплаты налогов «ассоциированным лицом» на уровне налогоплательщика. «Ассоциированное лицо» - это лицо, оказывающее услуги «соответствующему органу» (т. е. бизнесу, которому предъявлено обвинение в преступлении, связанном с неспособностью предотвратить содействие уклонению от уплаты налогов).

3. Неспособность соответствующего органа предотвратить уклонение от уплаты налогов: это является преступлением строгой ответственности, состоящим в том, что соответствующий орган не может помешать соответствующему лицу облегчить уклонение от уплаты налогов.

Иностранные преступления требуют двух дополнительных элементов:

1. Связь с Соединенным Королевством будет существовать, когда соответствующий орган инкорпорирован или сформирован в соответствии с законодательством Великобритании, осуществляет бизнес в Великобритании или если соответствующее поведение имеет место в Великобритании.

2. Двойная преступность: преступление должно быть незаконным как в Великобритании, так и в зарубежных юрисдикциях как на уровне налогоплательщика (вид 1), так и на уровне посредника (вид 2). 
Единственным средством защиты от этих преступлений является способность соответствующего органа продемонстрировать, что в момент совершения преступления:

- он имел «такие превентивные процедуры, какие было разумно при любых обстоятельствах ожидать», с тем, чтобы не допустить совершения ассоциированными лицами преступления;

- было бы неразумно при всех обстоятельствах ожидать, что соответствующий орган будет иметь такие профилактические процедуры.

Положения данного закона позволяют сделать вывод о том, что отсутствие уголовной ответственности юридических лиц в России (Букарев, Трунцевский, Шулепов, 2007) не позволяет в должной мере использовать потенциал хозяйствующих субъектов по внутреннему контролю, стимулировать руководством таких компаний инвестирование в соответствующие комплаенс-службы, а значит, применять эффективные меры противодействия налоговым преступлениям.

\section{СПИСОК ЛИТЕРАТУРЫ}

Букарев, В. Б., Трунцевский, Ю. В., Шулепов, Н. А. (2007) Зарубежный опыт в сфере правового регулирования противодействия легализации (отмыванию) доходов, приобретенных преступным путем // Международное публичное и частное право. № 4. С. 53-64.

Ищук, Я. Г. (2018) Коррупция: вопросы теоретического осмысления // Академическая мысль. № 1 (2). С. 45-50.

Ларичев, В. Д., Трунцевский, Ю. В., Баграев, С. П. (2007) Методика криминологического исследования налоговой преступности (вопросы совершенствования) : монография. М. : Изд. дом И. И. Шумиловой. 184 с.

Трунцевский, Ю. В. (2010) Российское уголовно-превентивное право: признаки отрасли // Российский криминологический взгляд. № 3. С. 165-173.

Трунцевский, Ю. В., Карпович, О.Г. (2013) Due diligence - правовой аудит хозяйствующих субъектов // Безопасность бизнеса. № 4. С. 22-25.

Трунцевский, Ю. В., Марьин, А. (2017) Законодательные меры предупреждения экономических преступлений и ответственности юридических лиц: новеллы и инициативы в Великобритании // Журнал зарубежного законодательства и сравнительного правоведения. № 6 (67). С. 93-98. DOI: 10.12737/ article_5a1e71dc311229.41899184

Дата поступления: 27.05.2018 2. 
Асриян Борис Андреевич — кандидат юридических наук, доцент кафедры уголовно-правовых и специальных дисциплин Московского гуманитарного университета. Адрес: 111395, Россия, г. Москва, ул. Юности 5, корп. 1. Тел.: +7 (499) 374-73-80. Эл. адрес: kafedraup@mosgu.ru

Asriyan Boris Andreevich, Candidate of Law, Associate Professor, Department of Criminal, Legal and Special Disciplines, Moscow University for the Humanities. Postal address: Bldg. 1, 5 Yunosti St., 111395 Moscow, Russian Federation. Tel.: +7 (499) 374-73-80. E-mail: kafedraup@mosgu.ru

Для циитирования:

Асриян Б. А. Закон Великобритании об уголовных финансах 2017 года для организаций [Электронный ресурс] // Горизонты гуманитарного знания. 2018. № 3. C. 110-115. URL: http://journals.mosgu.ru/ggz/article/view/802 (дата обращения: дд.мм.гггг). DOI: 10.17805/ggz.2018.3.8 